\title{
A cyclic peptide derived from $\alpha$-fetoprotein inhibits the proliferative effects of the epidermal growth factor and estradiol in MCF7 cells
}

\author{
CRISTIAN TORRES*, ELMER ANTILEO*, MARÍA JOSÉ EPUÑÁN, ANA MARÍA PINO, \\ LUIS EMILIO VALLADARES and WALTER DANIEL SIERRALTA \\ Laboratorio de Hormonas y Receptores, INTA-Universidad de Chile, \\ Avda. Macul 5540, Santiago 7830489, Chile
}

Received November 30, 2007; Accepted January 29, 2008

\begin{abstract}
A cyclic peptide derived from the active domain of $\alpha$-fetoprotein (AFP) significantly inhibited the proliferation of MCF7 cells stimulated with the epidermal growth factor (EGF) or estradiol $\left(\mathrm{E}_{2}\right)$. The action of these three agents on cell growth was independent of the presence of calf serum in the culture medium. Our results demonstrated that the cyclic peptide interfered markedly with the regulation of MAPK by activated c-erbB2. The cyclic peptide showed no effect on the $\mathrm{E}_{2}$-stimulated release of matrix metalloproteinases 2 and 9 nor on the shedding of heparin-binding EGF into the culture medium. We propose that the AFP-derived cyclic peptide represents a valuable novel antiproliferative agent for treating breast cancer.
\end{abstract}

\section{Introduction}

Estrogens have a major role in the growth and development of the mammary gland where they interact with other hormones, growth factors and cytokines in the precise regulation of proliferation and differentiation. Mammary cancer, the leading cancer in women worldwide, is known to be under hormonal control (1). Estradiol $\left(\mathrm{E}_{2}\right)$ stimulates the growth of certain breast tumors, activating relatively slow genomic processes, elicited by an association to nuclear estrogen receptors (ERs) and subsequent transactivation of target genes (2). Other cellular responses to $E_{2}$ involve the association of the hormone to cognate receptors located at the cell membrane

Correspondence to: Dr Walter D. Sierralta, Laboratorio de Hormonas y Receptores, INTA-Universidad de Chile, Avda. Macul 5540, Santiago 7830489, Chile

E-mail:wsierra@uchile.cl

${ }^{*}$ Contributed equally

Key words: MCF7 cells, estradiol, epidermal growth factor, $\alpha$ fetoprotein, cyclic peptide, heparin-binding epidermal growth factor
(mER) that promote the so-called 'non-genomic' $\mathrm{E}_{2}$ effects (3). Depending on the cell type and context, the association of $\mathrm{E}_{2}$ to the mER triggers several molecules, including calcium channels (4), cAMP (5), phospholipase C (6), inositol phosphate (7) and a variety of kinases (8). In addition, the association of $\mathrm{E}_{2}$ to $\mathrm{mER}$ transactivate members of the family of epidermal growth factor receptors (EGFRs), leading, among others, to downstream signaling by extracellular factor regulated kinases (ERK) (9-12).

Recent studies suggest that the EGFRs could be a nodal point of convergence for many membrane cytokine receptors with the capacity to activate ERK. $\mathrm{E}_{2}$ is known to activate signaling molecules, including IGF-IR, EGFR and MAPK in MCF7 breast cancer cells (13). Rapid ER $\alpha$ membrane translocation and interaction with membrane IGFR have been shown as prerequisite steps for $\mathrm{E}_{2}$-induced MAPK activation in these cells (14).

Hormonal therapies are important in treating ER-positive breast cancer patients and currently two pharmacological approaches are used to diminish the proliferative effects of $\mathrm{E}_{2}$. One is the inhibition of $\mathrm{E}_{2}$ action using anti-estrogens that interact with the ER, the other is the inhibition of estrogen synthesis by aromatase inhibitors (15). However, not every ER-positive breast cancer is sensitive to these treatments and, even worse, certain treated tumors eventually acquire a resistance to these therapeutical drugs. The development of antihormone resistance has been related with the sustained operation of extranuclear ER $\alpha$ pathways (8). Therefore, compounds that repress or annihilate $\mathrm{E}_{2}$-dependent activation of these pathways in growing cancer cells could become valuable therapeutic agents.

Studies by Mesfin et al demonstrated that a cyclic peptide (cP) containing a minimal active sequence from $\alpha$-fetoprotein (AFP) deter the growth of estrogen-dependent human mammary tumor cells xenoimplanted into severely immunodeficient (SCID) mice (16). Furthermore, these authors demonstrated that the $\mathrm{cP}$ inhibits the uterotrophic action of $\mathrm{E}_{2}$ and tamoxifen in immature mice and the proliferation of estrogen-dependent human tumor cells in culture $(17,18)$. The cyclic peptide showed stability in solution and is fully active in delaying mammary tumor growth when administered orally to rats (19). 
Recently, we demonstrated that $\mathrm{E}_{2}$-stimulated proliferation of mammary tumor cells was inhibited by the presence of the cyclic peptide in the culture medium (20). The peptide was effective slowing-down the proliferation of estrogen-dependent tumor cells, though not that of estrogen-independent MDAMB231 cells. The $\mathrm{cP}$ did not increase the MCF7 cell death rate, nor altered cell $\mathrm{E}_{2}$ binding capacity, nor modified cell aromatase activity (20).

The aim of this study was to compare the effect of the AFP-derived cyclic peptide on EGF- and $\mathrm{E}_{2}$-stimulated proliferation of MCF7 cells. Results indicate that the $\mathrm{cP}$ interferes in MAPK regulation by c-erbB2. Neither the $E_{2}$ stimulated release of MMP2 and MMP9 nor the shedding of heparin-binding EGF (HB-EGF) into the culture medium were affected by the cyclic peptide.

\section{Materials and methods}

Materials. The AFP-derived nonapeptide cyclo (EKTOV NOGN) (where O is hydroxyproline) and the controlscrambled peptide were obtained by solid-phase peptide synthesis using $\mathrm{N}$-(9-fluorenyl) methoxycarbonyl, as already described (18).

Tissue culture materials were obtained from NalgeNunc (Rochester, NY, USA), PVDF membranes and Precision Plus Protein Standards were purchased from BioRad Laboratories (Hercules, CA, USA). Recombinant human (rh) EGF (Cat GF001) was obtained from Chemicon International, Inc (Temecula, CA, USA). Protease inhibitor cocktail III and $\mathrm{E}_{2}$ were purchased from Calbiochem, EMD Biosciences (La Jolla, CA, USA). Most of the other substances used in this study were from Sigma-Aldrich (St. Louis, MO, USA).

Antibodies: mouse anti-c-erbB2 monoclonal antibody (sc-08); goat anti HB-EGF (sc-1414); rabbit anti-ERK polyclonal antibody (sc-154) and FITC-conjugated goat antimouse IgG (sc2010) were from Santa Cruz Biotechnology, Inc. (Santa Cruz, CA, USA). Rabbit anti-MAP kinase (M2360-02A, specifically recognizing ERKs p44, p42, phosphorylated in Thr202,Tyr204) was purchased from United States Biological (Swampscott, MA, USA). Mouse anti-EGFR monoclonal antibody (GR13) was obtained from Calbiochem, EMD Biosciences and Alexa Fluor 488 conjugated donkey anti-rabbit IgG (A21206) was purchased from Molecular Probes-Invitrogen Corp. (Carlsbad, CA, USA).

Cell lines. $\mathrm{E}_{2}$-sensitive MCF7 epithelial cells established from human metastatic breast cancer tissue (HTB 22; ATCC, USA), were cultured in MEM-Eagle media containing $10 \%$ calf serum, $1 \mathrm{mM}$ sodium pyruvate, $2 \mathrm{mM}$ L-glutamine, $100 \mathrm{U} / \mathrm{ml}$ penicillin and $100 \mu \mathrm{g} / \mathrm{ml}$ streptomycin. Calf serum was used instead of fetal bovine serum to avoid the presence of traces of AFP.

In the proliferation studies with the medium containing calf serum, the cells were transferred $24 \mathrm{~h}$ after seeding to DMEM F12 containing ITS (insulin, transferrin, selenium), $5 \%$ charcoal/dextran-twice-treated calf serum, $100 \mathrm{U} / \mathrm{ml}$ penicillin and $100 \mu \mathrm{g} / \mathrm{ml}$ streptomycin. Whereas in the proliferation studies under serum-free conditions, the cells were transferred to DMEM F12 containing ITS (insulin, transferrin, selenium), 3\% hydroxyethylated starch (HAES),
$0.5 \%$ human serum albumin, $50 \mathrm{U} / \mathrm{ml}$ penicillin and $50 \mu \mathrm{g} / \mathrm{ml}$ streptomycin. The $\mathrm{E}_{2}$-insensitive cell line MDA-MB231 (HTB-26; ATCC, USA), used for control studies, was cultured as described previously (20). In each of the experiments, the cells were incubated at $37^{\circ} \mathrm{C}$ in a humidified incubator, under a $5 \% \mathrm{CO}_{2}$ atmosphere.

Proliferation studies. MCF7 (12,000 cells/ $\left.\mathrm{cm}^{2}\right)$ and MDAMB231 (6,000 cells $\left./ \mathrm{cm}^{2}\right)$, were seeded and incubated for $24 \mathrm{~h}$ to allow attachment, non-adherent cells and media were removed. The remaining cells were washed and further incubated for various periods with the respective culture medium containing either $2 \mathrm{nM} \mathrm{E} \mathrm{E}_{2}$, or $5 \mathrm{ng} \mathrm{rh} \mathrm{EGF}$, in the absence or presence of $2 \mu \mathrm{g} / \mathrm{ml}$ of cyclic peptide, with a change of the culture medium every $48 \mathrm{~h}$. Parallel control experiments containing no $\mathrm{E}_{2}$ or cyclic peptide, or $2 \mu \mathrm{g} / \mathrm{ml}$ of a control, scrambled peptide were perfomed. At the completion of the incubation period, cells were washed with phosphatebuffered saline (PBS), detached $(0.25 \%$ trypsin in $0.2 \mathrm{mM}$ EDTA), re-suspended in PBS, counted and assessed for viability (trypan blue). Each experiment was performed three times.

Immunofluorescence studies. Cells exposed to different experimental conditions were grown on a sterile coverglass and then fixed (methanol, $20 \mathrm{~min}$ at $-20^{\circ} \mathrm{C}$ ), rinsed (PBS containing $2 \% \mathrm{BSA}$ ) and incubated with the primary antibodies ( $1 \mathrm{~h}$ at RT). After extensive washes (PBS containing $2 \% \mathrm{BSA}$ ), cells were incubated with the appropriate secondary antibody and nuclei counterstained with Hoechst 33240. After immunolabeling, cells were washed, mounted and viewed with a Zeiss Axiophot epifluorescence microscope fitted with a color CCD camera. In each experiment, the images were obtained under fixed settings of illumination, exposure times and camera gain.

Western blot analysis. For total cell protein extraction, cells were sonicated in $62.5 \mathrm{mM}$ Tris, $\mathrm{pH} 6.8$ containing 2\% SDS, $50 \mathrm{mM}$ DTT, $10 \%$ glycerol and $0.01 \%$ bromophenol blue. For electrophoresis, 10-20 $\mu \mathrm{g}$ protein samples were incubated for 5 min at $95^{\circ} \mathrm{C}$ and loaded in $10 \%$ polyacrylamide gels. Electrophoresis was carried out at RT at $100 \mathrm{~V}$ using BioRad's Miniprotean chambers. Bands were electro-transferred onto PVDF membranes, immunodetection was performed by using the appropriate primary antibodies and peroxidaselabelled secondary antibodies and visualizing by enhanced chemiluminescence (Renaissance Western blot chemiluminescence kit from Perkin Elmer, Boston, MA, USA). Phosphorylated ERK1/2 proteins were detected with the specific anti-phospho antibody and the rabbit antibody-antigen complexes were tagged as indicated above. Relative levels of total ERK1/2 protein in each sample were determined by stripping the phospho-specific ERK1/2 antibodies from the membrane and reprobing with antibodies to non-phosphorylated ERK1/2. The immunoblot bands were analyzed with NIH Image J software.

Gelatin zymography. MMP activities secreted into the culture medium by MCF7 cells were analyzed by gel electrophoresis. The cells were incubated for $48 \mathrm{~h}$ in a medium with $5 \%$ 
A

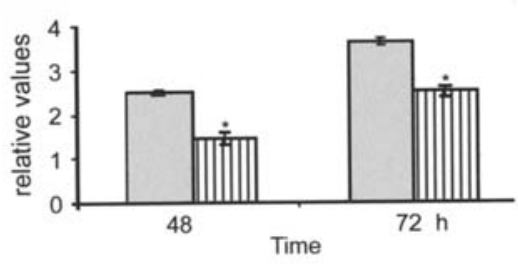

C

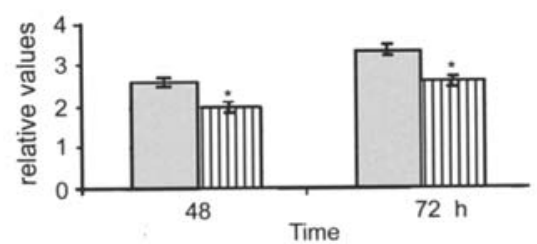

B

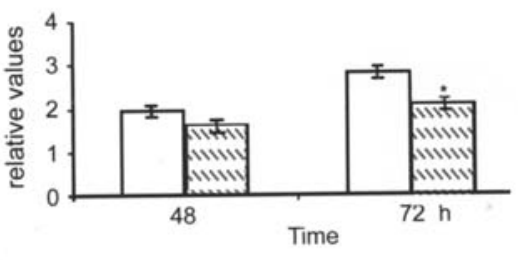

D

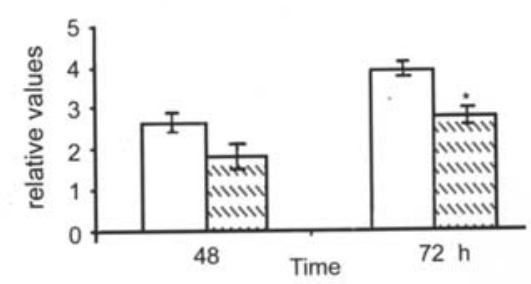

Figure 1. Effect of the $\mathrm{cP}$ on mitogen-stimulated proliferation of MCF7 cells in media with or without serum. MCF7 cells were incubated for indicated times in a medium with $5 \%$ CDCS containing $2 \mathrm{nM} \mathrm{E}$ (grey columns), $2 \mathrm{nM} \mathrm{E}$ plus $2 \mu \mathrm{g} / \mathrm{ml} \mathrm{cP}$ (vertically hatched columns) (A), $5 \mathrm{ng} / \mathrm{ml}$ EGF (open columns) or $5 \mathrm{ng} / \mathrm{ml} \mathrm{EGF}$ plus $2 \mu \mathrm{g} / \mathrm{ml} \mathrm{cP}$ (hatched columns) (B). MCF7 cells were incubated for indicated times in a medium with HAES in the presence of $2 \mathrm{nM} \mathrm{E}_{2}$ (grey columns), with $2 \mathrm{nM} \mathrm{E}$ plus $2 \mu \mathrm{g} / \mathrm{ml} \mathrm{cP}$ (vertically hatched columns) (C); $5 \mathrm{ng} / \mathrm{ml}$ EGF (open columns) or $5 \mathrm{ng} / \mathrm{ml}$ EGF plus cP (hatched columns) (D). Proliferation is expressed as a relative cell number in relation to control cell numbers $\left(24 \mathrm{~h}\right.$ after seeding $=11,700$ cells $\left./ \mathrm{cm}^{2}\right)$. Values are mean $\pm \mathrm{SD}$ of 3 experiments in triplicate. ${ }^{*} \mathrm{P}<0.05$ compared with results without $\mathrm{cP}$.

charcoal-treated calf-serum and then incubated for different periods of time with $2 \mathrm{nM} \mathrm{E}_{2}$ in the presence or absence of $2 \mu \mathrm{g} / \mathrm{ml} \mathrm{cP}$. The cell proliferation medium was removed, mixed with two volumes of SDS sample buffer $(0.125 \mathrm{M}$ Tris- $\mathrm{HCl}$, pH 6.8 containing $10 \%$ SDS, $8 \%$ sucrose and $0.05 \%$ bromophenol blue), incubated for $30 \mathrm{~min}$ at $25^{\circ} \mathrm{C}$ and applied on $7.5 \%$ polyacrylamide co-polymerized with $0.1 \%$ gelatin. The electrophoresis was performed as indicated previously. After the run, the gels were washed three times, 20 min each, with $2.5 \%$ Triton $\mathrm{X}-100$ at room temperature and then incubated for $10 \mathrm{~h}$ at $37^{\circ} \mathrm{C}$ in $50 \mathrm{mM}$ tris $\mathrm{pH} 7.4$ containing $5 \mathrm{mM} \mathrm{CaCl}_{2}$ and $0.5 \mathrm{mM} \mathrm{NaN}_{3}$. The gel was stained with $0.5 \%$ Coomassie blue and destained in acetic $\mathrm{acid} / \mathrm{methanol} \mathrm{solution.}$

Statistical analyses. Student's t-test was used to evaluate differences between samples and the respective controls. $\mathrm{P}<0.05$ was considered significant. Data were analyzed with Statistica for Windows Software, release 6, Statsoft Inc., USA.

\section{Results}

Effect of the cyclic peptide $(c P)$ on mitogen-stimulated proliferation of MCF7 cells. It has been suggested that the $\mathrm{E}_{2}$-dependent growth of cancer cells might involve the participation of the EGF signaling pathway, therefore, we analyzed whether the cyclic peptide modified the EGFdependent proliferation of MCF7 cells. For comparison, the cells were treated with $2 \mathrm{nM} \mathrm{E}_{2}$, in the presence or absence of $2 \mu \mathrm{g} / \mathrm{ml} \mathrm{cP}$.

$\mathrm{E}_{2}$-stimulated MCF7 cell proliferation in a serum containing culture medium, which was significantly inhibited in the presence of $2 \mu \mathrm{g} / \mathrm{ml}$ of the cyclic peptide by 46 and $29 \%$ after 48 and 72 h of treatment, respectively (Fig. 1A).

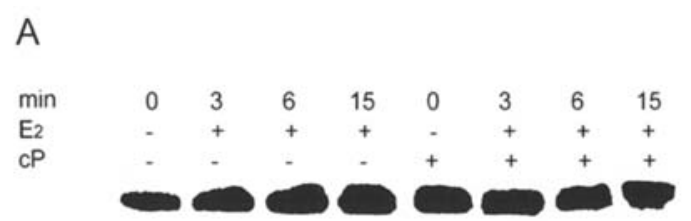

B

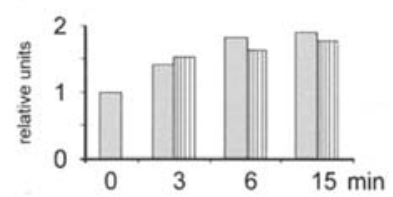

C

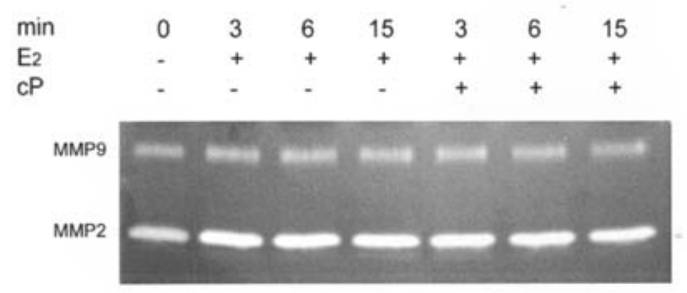

Figure 2. HB-EGF shedding upon $\mathrm{E}_{2}$ stimulation. (A) Western blot of HBEGF after short-time stimulation of MCF7 cells with $\mathrm{E}_{2}$ in the absence or presence of $\mathrm{cP}$. (B) Histogram of HB-EGF shedding after $\mathrm{E}_{2}$ stimulation in the absence (grey bars) and presence of $\mathrm{cP}$ (hatched bars). (C) Analysis of MMP2 and MMP9 secretion into the culture medium. The cells were incubated with $2 \mathrm{nM} \mathrm{E}_{2}$ in the absence or presence of $2 \mu \mathrm{g} / \mathrm{ml} \mathrm{cP}$. The MMP2 and -9 gelatinase activities in the culture medium were analyzed by zymography.

Studies on MCF7 cell growth in serum-containing medium with different amounts of recombinant human EGF showed that $5 \mathrm{ng} / \mathrm{ml}$ EGF was a dose sufficient to obtain maximal proliferation. The cells grew slower under EGF than 


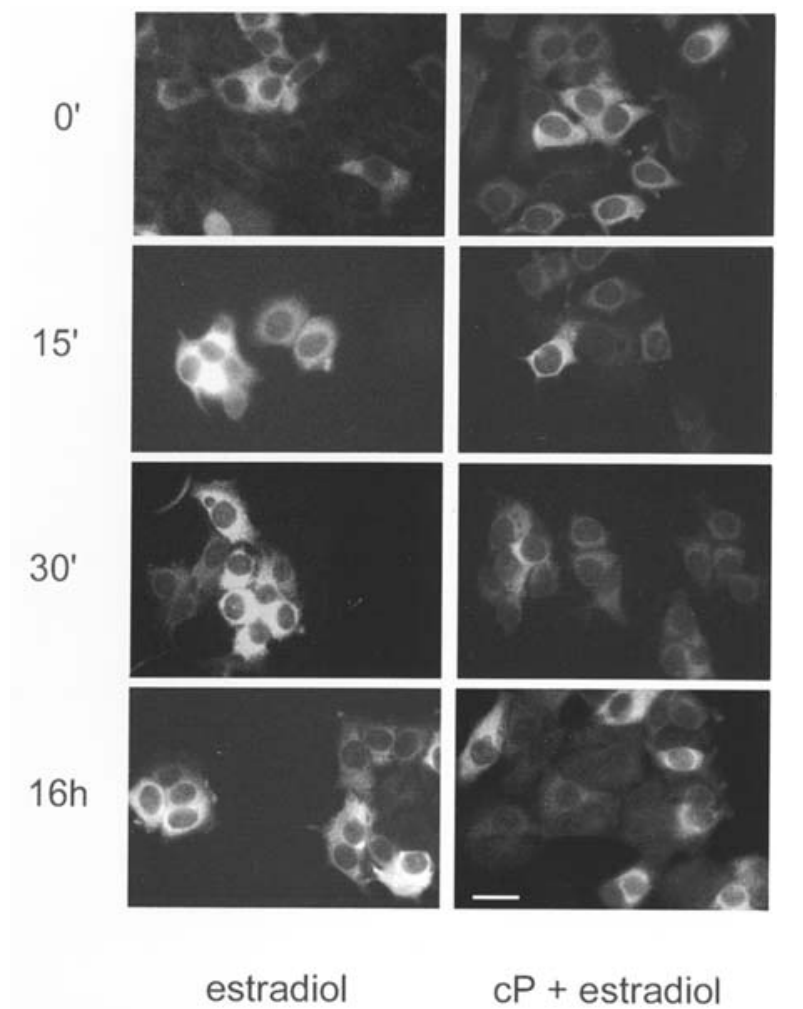

Figure 3. Immunofluorescence for c-erbB2 in MCF7 cells stimulated with $\mathrm{E}_{2}$. Representative images of c-erbB2 in MCF7 cells grown for $48 \mathrm{~h}$ in a medium containing $5 \% \mathrm{CDCS}$ and then stimulated for indicated times with $2 \mathrm{nM} \mathrm{E}_{2}$ alone (left) or $\mathrm{E}_{2}$ and $2 \mu \mathrm{g} / \mathrm{ml} \mathrm{cP}$ (right), or vehicle alone (0 min). The bar represents $50 \mu \mathrm{m}$.

under $\mathrm{E}_{2}$ (Fig. 1B). The cyclic peptide at $2 \mu \mathrm{g} / \mathrm{ml}$ inhibited effectively the EGF-stimulated cell proliferation, allowing a significant inhibition of 18 and $25 \%$ after 48 and $72 \mathrm{~h}$, respectively.

The cyclic peptide exhibited significant antiproliferative effects on other mamary tumor cells such as ZR-75 and various ER $\alpha$-positive primarily-cultured canine mammary tumor cells (unpublished data), however the compound had no effect on the growth of $\mathrm{E}_{2}$-independent tumor cells, such as MDA-MB231 (20) nor on the proliferation of normal cells, such as HUVEC (not shown).

Parallel studies were run in a medium without serum. Previously, we tested several serum-free culture formulations that allowed cell proliferation for at least $96 \mathrm{~h}$, selecting as appropriate DMEM F12 containing 3\% HAES, $10 \mu \mathrm{g} / \mathrm{ml}$ insulin, $5.5 \mu \mathrm{g} / \mathrm{ml}$ transferrin and $0.5 \%$ human serum albumin. Results shown in Fig. 1C allowed discarding serum effects on the $\mathrm{cP}$ inhibitory action, since analogous inhibition of 40 and $22 \%$ after 48 and $72 \mathrm{~h}$ of treatment respectively, were observed in a medium without serum. The inhibitory effect of the $\mathrm{cP}$ was structure-dependent as the addition $2 \mu \mathrm{g} / \mathrm{ml}$ of a scrambled peptide did not affect the estrogen-dependent growth of these cells (not shown).

As shown in Fig. 1D, the stimulatory effect of $5 \mathrm{ng} / \mathrm{ml} \mathrm{rh}$ EGF on cell proliferation was effective in a serum-free medium: $2 \mu \mathrm{g} / \mathrm{ml}$ cyclic peptide significantly inhibited EGF-stimulated cell growth by 36 and $29 \%$ after 48 and $72 \mathrm{~h}$, respectively. $0^{\prime}$
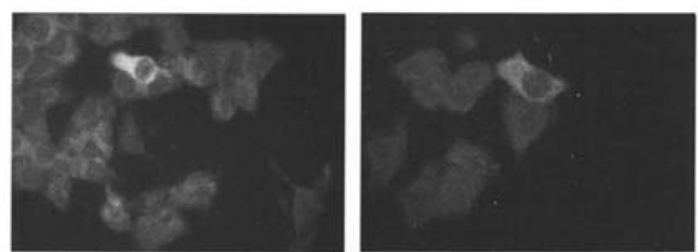

$15^{\prime}$
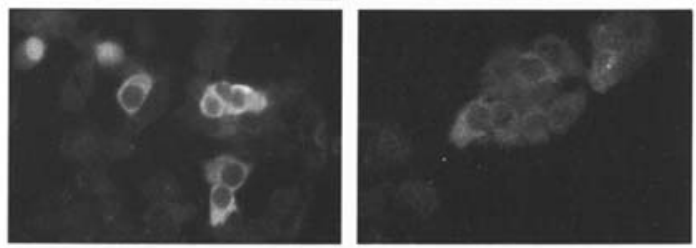

30
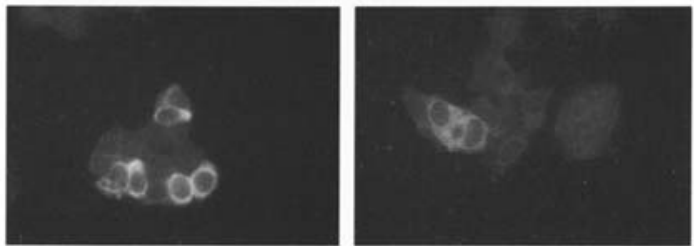

$16 \mathrm{~h}$

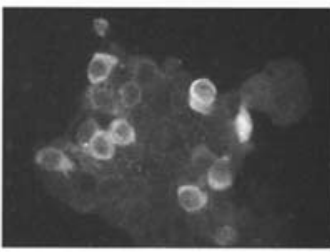

EGF

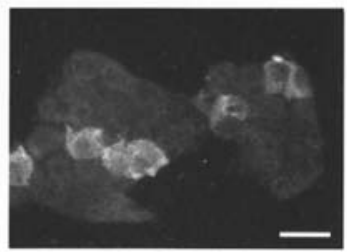

$c P+E G F$
Figure 4. Immunofluorescence for c-erbB2 in MCF7 cells stimulated with EGF. Representative images of c-erbB2 in MCF7 cells grown for $48 \mathrm{~h}$ in a medium containing 5\% CDCS and then stimulated for indicated times with $5 \mathrm{ng} / \mathrm{ml} \mathrm{rh} \mathrm{EGF} \mathrm{alone} \mathrm{(left)} \mathrm{or} \mathrm{rh} \mathrm{EGF} \mathrm{and} 2 \mu \mathrm{g} / \mathrm{ml} \mathrm{cP}$ (right), or vehicle alone $(0 \mathrm{~min})$. The bar represents $50 \mu \mathrm{m}$.

The $\mathrm{cP}$ inhibitory action is not related to $H B-E G F$ releasing by cells. $\mathrm{E}_{2}$ treatment of MCF7 cells activates the rapid shedding of HB-EGF, enhancing the availability of the growth factor (Fig. 2A). We tested whether the presence of the cyclic peptide altered this $\mathrm{E}_{2}$ effect on cells. Western blots for HB-EGF showed that after $\mathrm{E}_{2}$ stimulation of cells either in the absence or presence of the cyclic peptide, the level of this growth factor in cells increased rapidly (Fig. 2B). In agreement with this observation, we determined that the cyclic peptide had no effect on the $\mathrm{E}_{2}$-stimulated release of MMP2 and MMP9 into the culture medium (Fig. 2C).

The inhibitory effect of $c P$ is related to $c$-erbB2 reactivity. The expression of the c-erbB2 protein by MCF7 cells after short-term treatment with $\mathrm{E}_{2}$, in the absence or presence of the cyclic peptide was analyzed by using indirect immunofluorescence. Fig. 3 shows that $2 \mathrm{nM} \mathrm{E}_{2}$ increased c-erbB2 immunoreactivity in the cells within $15 \mathrm{~min}$ of treatment. In contrast, c-erbB2 immunofluorescence was markedly reduced in the presence of the cyclic peptide, remaining low even after $16 \mathrm{~h}$ of treatment (Fig. 3). The treatment of cells with the scrambled peptide did not affect c-erbB2 immunoreactivity. Analogous results were observed in cells incubated in a serum-free medium (not shown). Similar results were observed upon $5 \mathrm{ng} / \mathrm{ml} \mathrm{rh}$ EGF treatment of MCF7 cells; this growth factor induced an early increase in c-erbB2 
A
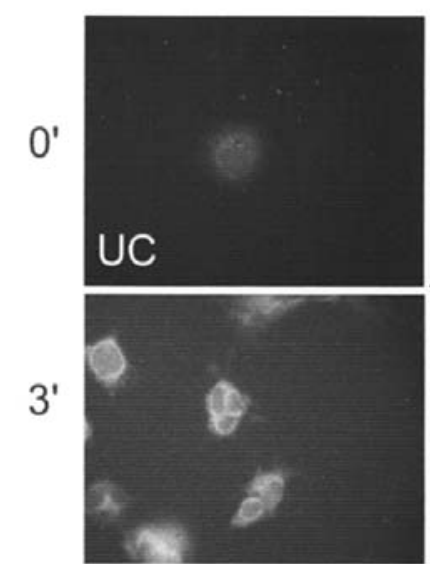

$6^{\prime}$

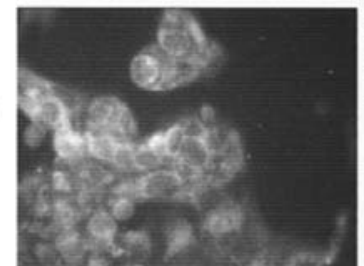

9'

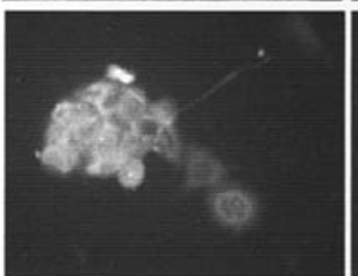

$15^{\prime}$

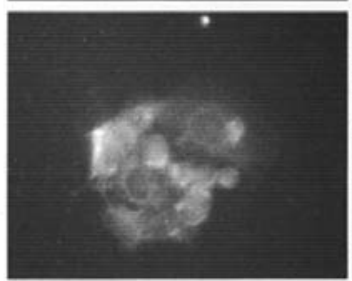

E2
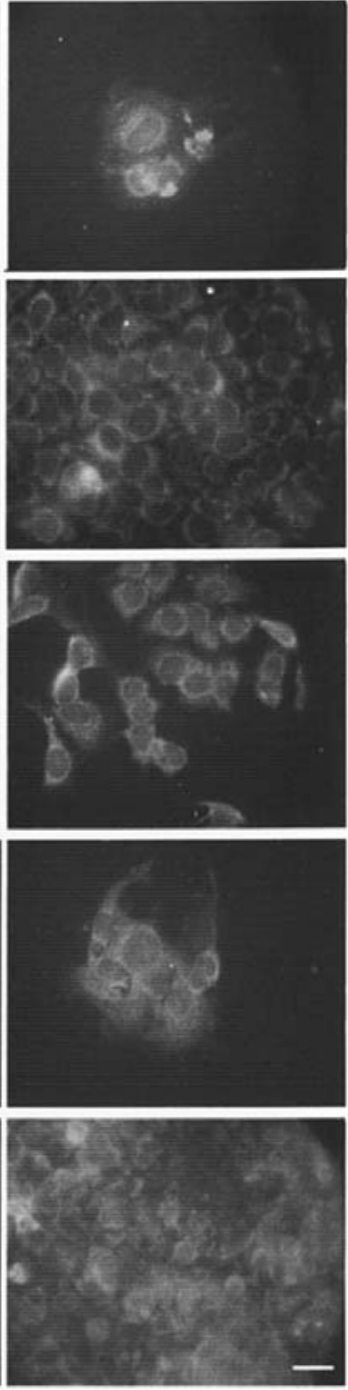

$\mathrm{E} 2+\mathrm{cP}$
B

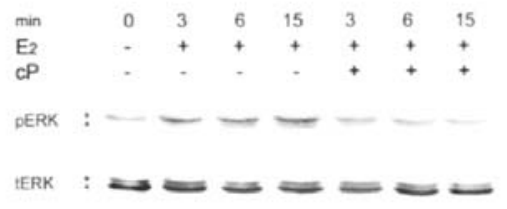

C

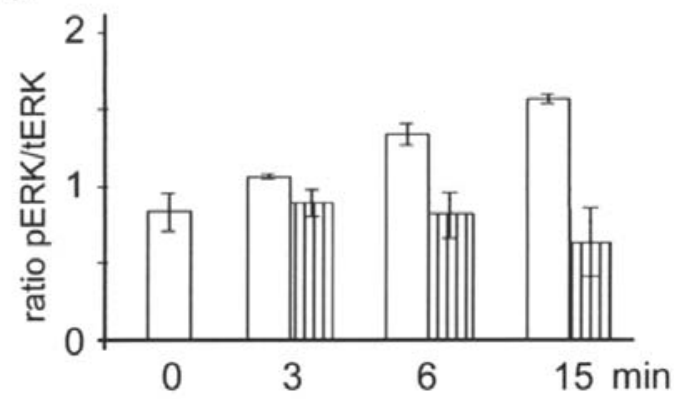

Figure 5. Immunological studies of MAPK in MCF7 cells stimulated with $\mathrm{E}_{2}$. (A) Immunofluorescence for pErk1/2 in cells grown for $48 \mathrm{~h}$ in a medium containing 5\% CDSS and stimulated for indicated times with $2 \mathrm{nM} \mathrm{E}$ (left) or $\mathrm{E}_{2}$ plus $2 \mu \mathrm{g} / \mathrm{ml} \mathrm{cP}$ (right) or after the addition of vehicle alone (0 min). $\mathrm{UC}$, Unspecific control. The bar represents $50 \mu \mathrm{m}$. (B) MCF7 cells were treated with $2 \mathrm{nM} \mathrm{E} 2$ in the absence or presence of $2 \mu \mathrm{g} / \mathrm{ml} \mathrm{cP}$ for the indicated periods of time. Cell lysates were collected and ERK1/2 phosphorylation was assessed in $10 \mu \mathrm{g}$ protein samples by Western blot analysis. The histogram shows the ratios between phosphorylated and total ERK1/2 in cells stimulated for the indicated times with $\mathrm{E}_{2}$ in the absence (open bars) or presence of cP (hatched bars); mean \pm range from 2 independent experiments.

immunoreactivity, which was clearly inhibited by the addition of $2 \mu \mathrm{g} / \mathrm{ml}$ cyclic peptide to the culture medium (Fig. 4).

The activation of $\mathrm{mRE}_{2}$ and EGFRs triggers intracellular signalling pathways leading to ERK phosphorylation and subsequent enhanced cell proliferation. In agreement with this, a rapid increase in immunoreactivity for phosphorylated ERK1/2 was observed after $\mathrm{E}_{2}$ or EGF treatment of MCF7 cells (Figs. 5A and 6A). In contrast, in the presence of the cyclic peptide, the immunoreactivity for phosphorylated ERK1/2 remained low (Figs. 5A and 6A). These observations were corroborated by Western blotting, which showed a significant decrease of phosphorylated ERK1/2 in $\mathrm{E}_{2^{-}}$and EGF-stimulated cells in the presence of the cyclic peptide (Figs. 5B and $\mathrm{C}$ and 6B and $\mathrm{C}$ ).

\section{Discussion}

The proliferation of MCF7 cells increased 20-35\% over nonstimulated controls in the presence of either $2 \mathrm{nM} \mathrm{E}_{2}$ or $5 \mathrm{ng} / \mathrm{ml}$ rh EGF (Fig. 1). Similar augments of cell growth were obtained using $5 \mathrm{ng} / \mathrm{ml} \mathrm{TGF} \alpha$ (not shown). A dose of $2 \mu \mathrm{g} / \mathrm{ml}$ $\mathrm{cP}$ effectively hindered the effect of mitogens on the proliferation.

The effects of these mitogens and of $\mathrm{cP}$ on the proliferation of MCF7 cells were also observed in serum-free medium, indicating that serum factors are not required for the activities of these molecules. The maintenance of cells in serum-free conditions proved that $10 \mu \mathrm{g} / \mathrm{ml}$ insulin present in the medium is sufficient for keeping the cells alive and 


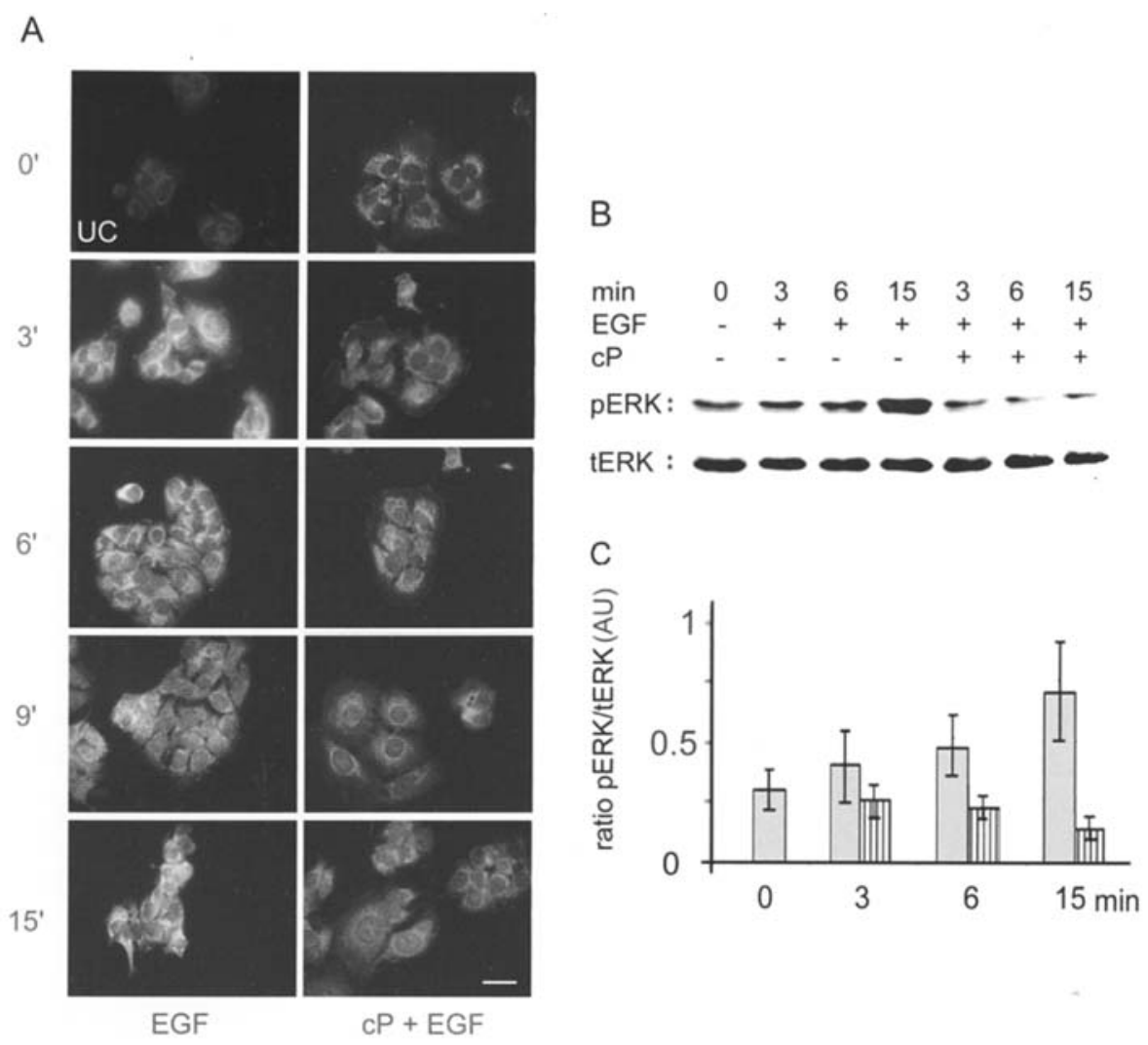

Figure 6. Immunological studies of MAPK in MCF7 cells stimulated with EGF. (A) Immunofluorescence for pErk1/2 in cells grown for $48 \mathrm{~h}$ in a medium containing 5\% CDSS and stimulated for indicated times with $5 \mathrm{ng} / \mathrm{ml}$ EGF (left) or EGF plus $2 \mu \mathrm{g} / \mathrm{ml} \mathrm{cP}$ (right), or after the addition of vehicle alone (0 min). UC, Unspecific control. The bar represents $50 \mu \mathrm{m}$. (B) MCF7 cells were treated with $5 \mathrm{ng} / \mathrm{ml} \mathrm{rh} \mathrm{EGF} \mathrm{in} \mathrm{the} \mathrm{absence} \mathrm{or} \mathrm{presence} \mathrm{of} 2 \mu \mathrm{g} / \mathrm{ml} \mathrm{cP}$ for the indicated period of time. Cell lysates were collected and ERK1/2 phosphorylation was assessed in $10 \mu \mathrm{g}$ protein samples by Western blot analysis. The histogram shows the ratios between phosphorylated and total ERK1/2 in cells stimulated for the indicated times with rhEGF in the absence (grey bars) or presence of $\mathrm{cP}$ (hatched bars); mean \pm range from 2 independent experiments.

proliferating, albeit at a reduced rate, for at least $96 \mathrm{~h}$. The respective effects of $E_{2}, E G F, T G F \alpha$ and of the cyclic peptide on the cell proliferation were observed, practically at the same magnitude, in MCF7 cells cultured in the presence or absence of calf serum, indicating that no other serum factors are required for the corresponding activities of these molecules.

The fluorescence studies using the specific monoclonal antibody demonstrated early increases of c-erbB2 immunoreactivity in cells stimulated with $\mathrm{E}_{2}$ or with rh EGF, again independently of the presence of serum. The stimulatory effects of $E_{2}$ and rh EGF (and of TGF $\alpha$ ) on c-erbB2 IR were similar, supporting reported data from others and pointing to the sharing of the signal transduction pathway involving members from the EGF receptor family (10-13). The results demonstrated that the activation of EGFR2, highly expressed in MCF7 cells, increases following the treatment of cells with rh EGF or $\mathrm{E}_{2}$. The cyclic peptide hindered any increase of c-erbB2 immunoreactivity by the mitogens, suggesting that the compound might interfere with the dimerization of this receptor. It would seem that the ligand-induced increase in EGF-IR will lead to augmented tyrosine kinase-specific activity of c-erbB2.

The treatment of MCF7 cells with either rh EGF or $\mathrm{E}_{2}$ caused a time-dependent augment of ERK1 phosphorylation and, to a lesser extent, of ERK2 (Figs. 5B and 6B). It has been shown that diverse ligand-activated receptors induce ERKs phosphorylation through members of the EGFR family
(21). The induction of ERK phosphorylation in MCF7 cells confirms the participation of the EGFR tyrosine kinase in $\mathrm{E}_{2}$ and EGF signaling, as reported by several groups $(8,10-15)$. Our experiments detected a clear reduction of ERK activation in the presence of $\mathrm{cP}$. Therefore, we conclude that the $\mathrm{cP}$ prevents c-erbB2 transactivation of the rise in phosphorylated ERK1/2 observed after mitogenic stimuli. As intermediate effectors of the Ras/ERK pathway, phosphorylated ERKs participate in the control of cellular proliferation (12). The Ras/ERK pathway represents a major mitogenic pathway, though at present there is not enough information on the precise mechanisms by which ERKs influence the cell cycle (22). It has been proposed that the interplay between cyclins and $\mathrm{p} 21 \mathrm{KipC} 1$ regulated by ERKs is of major significance in the regulation of the cycle (23). In this context, it is appropriate to refer to our former results, demonstrating that MCF7 cells exposed to $\mathrm{cP}$ exhibit increased nuclear $\mathrm{p} 21 \mathrm{KipC} 1$ expression (20).

Many studies have shown that $\mathrm{E}_{2}$ transactivates the EGFR via the shedding of the cell surface-bound HB-EGF. In MCF7 and other sensitive cells, the release of HB-EGF requires the active participation of MMP-2 and MMP-9 (11). We detected no effect of the $\mathrm{cP}$ on $\mathrm{E}_{2}$-stimulated shedding of HB-EGF by MCF7 cells and found no alterations in MMP2 and MMP9 secretion, as compared with cells stimulated with $\mathrm{E}_{2}$ only (Fig. 2). Therefore, we localize the effect of $\mathrm{cP}$ on cell proliferation mainly at the level of c-erbB2 activity. 
The precise molecular explanation of our findings remains to be determined, however a functional interplay between members of the EGF receptor family in mammary tumor cells seems to be in compliance with observations performed by other groups. Altogether, the results confirm the concept that the increment in the proliferation of mammary epithelial cells cultured in the presence of insulin depends upon EGF, TGF $\alpha$ or $E_{2}$. Many studies have shown that the stimulation of EGFR and IGF-IR is necessary for the sustained proliferation of mammary tumor cells (24) and plausible molecular explanations for these findings have been provided (21). Their main conclusion is that the EGFR pathway is necessary for the proliferation of mammary epithelial cells because of the control of MAPK activity. The involvement of this pathway in cell proliferation has supported the application of EGFR tyrosine kinase inhibitors for the treatment of diverse forms of cancers with the overexpression of EGFRs (25). Whether the cyclic peptide acts in a similar way to that of these inhibitors or not remains to be elucidated.

Breast cancer cells are often intrinsically resistant or become resistant to antiestrogens during treatment, therefore concrete requirement exists for additional effective drugs with minimal or no associated host toxicity in the treatment and prevention of breast neoplasias. The data presented in this study endorses the effectiveness of the AFP-derived cyclic peptide as an antiproliferative agent. This, together with previous data on its distinct mechanism of action, its low toxicity for the host and its effectiveness by oral administration (18-20), allows us to conclude that the cyclic peptide compound represents a valuable novel tool for fighting breast cancer.

\section{Acknowledgements}

We are grateful to Professors H.I. Jacobson, J. Bennett and T.T. Andersen (Albany Medical College, NY, USA) for providing the $\mathrm{cP}$ and the scrambled peptide. This study was supported by Fondecyt Chile, Grant 1040881.

\section{References}

1. Russo J and Russo IH: The role of estrogen in the initiation of breast cancer. J Steroid Biochem Mol Biol 102: 89-96, 2006.

2. McDonnel DP and Norris JD: Connections and regulation of the human estrogen receptor. Science 296: 1642-1644, 2002.

3. Simoncini T and Genazzani AR: Non-genomic actions of sex steroid hormones. Eur J Endocrinol 148: 281-292, 2003.

4. Tesarik J and Mendoza C: Nongenomic effects of 17 B-estradiol on maturing human oocytes: relationship to oocyte developmental potential. J Clin Endocrinol Metab 80: 1438-1443, 1995.

5. Aronica SM, Kraus WL and Katzenellenbogen BS: Estrogen action via the cAMP signalling pathway: stimulation of adenylate cyclase and cAMP-regulated gene transcription. Proc Natl Acad Sci USA 91: 8517-8522, 1994.

6. Le Mellay V, Grosse B and Lieberherr M: Phospholipase C $B$ and membrane action of calcitriol and estradiol. J Biol Chem 272: 11902-11907, 1997.

7. Lieberherr M, Grosse B, Kachkache M and Balsan S: Cell signaling and estrogens in female rat osteoblasts: a possible involvement of unconventional non-nuclear receptors. J Bone Miner Res 8: 1365-1376, 1993.
8. Kelly MJ and Levin ER: Rapid actions of plasma membrane estrogen receptors. Trends Endocrinol Metab 12: 152-156, 2001.

9. Filardo EJ, Quinn JA, Frackelton AR Jr and Bland KI: Estrogen action via the G protein-coupled receptor, GPR30: stimulation of adenylyl cyclase and cAMP-mediated attenuation of the epidermal growth factor receptor-to-MAPK signaling axis. Mol Endocrinol 16: 70-84, 2002.

10. Levin ER: Bidirectional signaling between the estrogen receptor and the epidermal growth factor receptor. Mol Endocrinol 17: 309-317, 2003.

11. Razandi M, Pedram A, Park ST and Levin ER: Proximal events in signaling by plasma membrane estrogen receptors. J Biol Chem 278: 2701-2712, 2003.

12. Zhang W and Liu HT: MAPK signal pathways in the regulation of cell proliferation in mammalian cells. Cell Res 12: 9-18, 2002.

13. Song RXD, Zhang ZH, Chen Y, Bao Y and Santen RJ: Estrogen signaling via a linear pathway involving insulin-like growth factor I receptor, matrix metalloproteinases, and epidermal growth factor receptor to activate mitogen-activated protein kinase in MCF7 breast cancer cells. Endocrinology 148: 4091-4101, 2007

14. Wyckoff MH, Chambliss KL, Mineo C, Yuhanna IS, Mendelsohn ME, Mumby SM and Shaul PW: Plasma membrane estrogen receptors are coupled to endothelial nitric oxide synthase through Ga(i). J Biol Chem 276: 27071-27076, 2001.

15. Thiantanawat A, Long BJ and Brodie AM: Signaling pathways of apoptosis activated by aromatase inhibitors and antiestrogens. Cancer Res 63: 8037-8050, 2003.

16. Mesfin FB, Andersen TT, Jacobson HI, Zhu SJ and Bennett JA: Development of a synthetic cyclized peptide derived from alpha-fetoprotein that prevents the growth of human breast cancer. J Pept Res 58: 246-256, 2001.

17. Bennett JA, Mesfin JA, Zhu SJ, Gierthy JF, Jacobson HI and Andersen TT: A peptide derived from alpha-fetoprotein prevents the growth of estrogen-dependent human breast cancers sensitive and resistant to tamoxifen. Proc Natl Acad Sci USA 99: 2211-2215, 2002

18. DeFreest LA, Mesfin FB, Joseph L, McLeod DJ, Stallmer A, Reddy S, Balulad SS, Jacobson HI, Andersen TT and Bennett JA: Synthethic peptide derived from alpha-fetoprotein inhibits growth of human breast cancer: investigation of the pharmacophore and synthesis optimization. J Pept Res 63: 409-419, 2004.

19. Bennett JA, DeFreest L, Anaka I, Saadati H, Balulad S, Jacobson HI and Andersen TT: AFPep: an anti-breast cancer peptide that is orally active. Breast Cancer Res Treat 98: 133-141, 2006.

20. Sierralta WD, Epuñan MJ, Reyes JM, Valladares LE, Andersen TT, Bennett JA, Jacobson HI and Pino AM: A peptide derived from alpha-fetoprotein inhibits the proliferation induced by estradiol in mammary tumor cells in culture. Oncol Rep 19: 229-235, 2008.

21. Ahmad T, Farnie G, Bundred NJ and Anderson NG: The mitogenic action of insulin-like growth factor I in normal human mammary epithelial cells requires the epidermal growth factor receptor tyrosine kinase. J Biol Chem 279: 1713-1719, 2004

22. Chang F, Steelman LS, Shelton JG, Lee JT, Navolanic PM, Blalock WL, Franklin R and McCubrey JA: Regulation of cell cycle progression and apoptosis by the Ras/Raf/MEK/ERK pathway. Int J Oncol 22: 469-480, 2003.

23. Roovers $\mathrm{K}$ and Assoian RK: Integrating the MAP kinase signal into the G1 phase cell cycle machinery. Bioessays 22: 818-826, 2000.

24. Ram TG, Kokeny KE, Dilts CA and Ethier SP: Mitogenic activity of neu differentiation factor/heregulin mimics that of epidermal growth factor and insulin-like growth factor-I in human mammary epithelial cells. J Cell Physiol 163: 589-596, 1995.

25. Thomas M: Overview of clinical trials with epidermal growth factor receptor inhibitors in advanced non-small cell lung cancer. Semin Oncol Nurs 18: 20-27, 2002. 